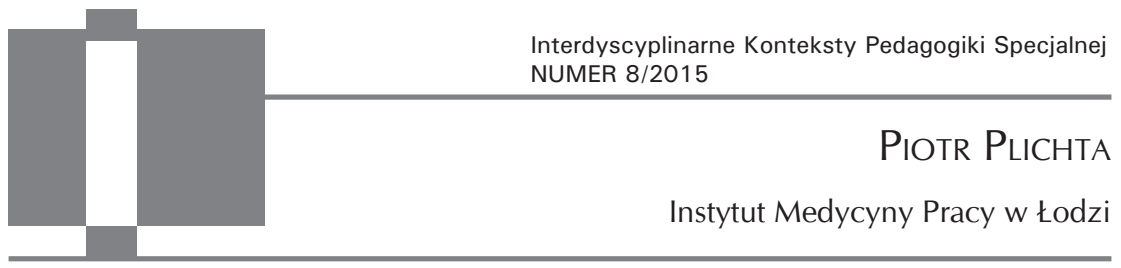

\title{
O czym marzą uczniowie z niepełnosprawnością intelektualną?
}

\begin{abstract}
Aвstract: Piotr Plichta, Dreams of pupils with intellectual disability [O czym marzą uczniowie z niepełnosprawnością intelektualną?]. Interdyscyplinarne Konteksty Pedagogiki Specjalnej, nr 8, Poznań 2015. Pp. 35-42. Adam Mickiewicz University Press. ISBN 978-83-232-2902-5. ISSN 2300-391X.
\end{abstract}

The article presents results of tematic analysis of interviews with students with mild and moderate intellectual disability. The sample was consisted of 62 young people attending 48 special schools in Łódź voivodship (12-16 years old). Tematic analysis identified the following categories of dreams: escape dreams, proffessional/career dreams, material dreams, idealistic/universal dreams, "celebrity" dreams, dreams „right here and now," lack of dreams (difficulties with identification included) and compound of the aforementiond dream categories. The data show that the most prevalent category of dreams were those related to future work, job, professional career. It proves importance of vocational rehabilitation provided for people with intellectual disability.

KEY wORDS: dreams, intellectual disability, special school.

Prawdziwe szczęście daje jedynie marzenie o przyszłym szczęściu.

Blaise Pascal

Czasem nierealne marzenie może stać się realnym koszmarem.

Karol Boromeusz 


\section{Wprowadzenie i założenia badawcze}

Prezentowana praca ma charakter doniesienia z badań, z części poświęconej marzeniom osób $\mathrm{z}$ niepełnosprawnością intelektualną - wątkowi w niewielkim stopniu dotąd analizowanemu na gruncie pedagogiki specjalnej. Rozważania na temat marzeń można umiejscowić w nurcie myślenia potocznego, jak również naukowej refleksji dotyczącej pragnień jednostki i ich roli w życiu, np. w kierowaniu własnym postępowaniem czy znaczeniu dla jakości życia. Najczęściej jednak o marzeniach wypowiadają się poeci, pisarze lub filozofowie.

Marzenia mogą mieć charakter diagnostyczny, ponieważ w zwerbalizowanych pragnieniach można dostrzec odniesienia do świata wartości (np. co uważa się za naprawdę ważne), sensu, motywów postępowania, celów, które chcemy osiągnąć lub które mogą być w danej sytuacji nieosiągalne. Marzenia mogą być wyrazem tego, czego w życiu brakuje, mogą zarówno motywować, jak i być na tyle nierealistyczne, że nie będą pobudzać do działania. Z punktu widzenia pracy wychowawczej ważne jest, by mieć rozeznanie w pragnieniach i marzeniach podopiecznych, ponieważ mogą one przejawiać się w różnych obszarach życia, np. w gotowości do uczenia się lub podejmowania wyzwań. Ich posiadanie bądź brak może być również wyrazem pewnej filozofii życiowej oraz stosunku do świata i miejsca jakie się w nim zajmuje. Grupy marginalizowane, a wśród nich osoby z niepełnosprawnością intelektualną, mają mniejsze szanse na realizację swoich marzeń. Pierwszym krokiem w tym kierunku powinno być zatem ich rozpoznanie.

Materiał badawczy stanowiły wypowiedzi z wywiadów, w których wzięło udział 62 uczniów z lekką i umiarkowaną niepełnosprawnością intelektualną z 24 szkół podstawowych i 24 gimnazjów z województwa łódzkiego (losowa próba szkół). W próbie znalazło się 45 chłopców i 17 dziewcząt od klasy IV szkoły podstawowej wzwyż (11-16 lat). Wywiady stanowiły część badania zrealizowanego w okresie od maja do czerwca 2015 r. przez zespół Krajowego Centrum Promocji Zdrowia w Miejscu Pracy w Instytucie Medycyny Pracy w Łodzi, pod kierunkiem Jacka Pyżalskiego, na zlecenie 
Regionalnego Centrum Polityki Społecznej w Łodzi, pt. „Potrzeby i satysfakcja z wybranych usług skierowanych do rodzin z dziećmi z orzeczoną niepełnosprawnością w wieku 8-16 lat". Oprócz analizowanej kwestii (marzeń respondentów) wywiad dotyczył oceny szkoły, do której uczęszczali badani uczniowie, oczekiwań i obszarów potencjalnej zmiany w tym zakresie, oceny jakości relacji koleżeńskich, w tym nieprzyjemnych sytuacji, np. doświadczania przemocy rówieśniczej, odczuwanych trudności, oceny otrzymywanego wsparcia, osób pomagających w trudnych sytuacjach, spędzania wolnego czasu, posiadania przyjaciół, zakresu i oceny satysfakcji z wykorzystywania nowych mediów (komputera, Internetu). Poznawanie perspektywy uczniów z niepełnosprawnością intelektualną $\mathrm{w}$ instytucjonalnie podejmowanych analizach nie jest powszechnie stosowane, więc w pewnym zakresie mieli oni w tych badaniach możliwość wypowiadania się własnym głosem w sprawach ich dotyczących.

W analizie wypowiedzi wykorzystano podejście eklektyczne, oparte na metodologii mieszanej, ilościowo-jakościowej (mix method research, multimethodology). Wypowiedzi badanych uczniów zostały poddane analizie tematycznej (tematic analysis), a następnie - jako dane jakościowe - ograniczonej kwantyfikacji. Wymiar ilościowy analizy ma tylko charakter orientacyjny i uzupełniający. Główny nacisk został położony na wyodrębnienie wątków tematycznych w zakresie posiadanych marzeń, pojawiających się w wypowiedziach uczniów. Jest to zarazem główny cel prezentowanego badania. Wyboru kryteriów analizy wypowiedzi dokonano ex post (po przeanalizowaniu zebranego materiału), co pozwoliło na uwzględnienie perspektywy badanych uczniów, a nie jedynie dopasowanie ich do przyjętych z góry założeń.

W przytaczanych wypowiedziach $\mathrm{w}$ indywidualnych kodach umieszczony jest tylko numer wywiadu, typ szkoły (podstawowa/ gimnazjum: SP/G) i płeć badanego ucznia (chłopiec/dziewczynka: C/D) np. kod (D1, G, C) oznacza wywiad numer jeden z uczniem gimnazjum, chłopcem. 


\section{Marzenia uczniów \\ z niepełnosprawnością intelektualną - wyniki analizy tematycznej}

Analiza tematyczna odpowiedzi uczniów na pytanie: "Jeśli możesz, to powiedz nam, jakie masz największe marzenie?" pozwoliła na zidentyfikowanie następujących, głównych wątków: brak marzeń (lub trudności ze sformułowaniem), marzenia o charakterze ucieczkowym (porzucenia miejsca, rodziny, sposobu życia), marzenia o charakterze zawodowym i związane z karierą oraz dotyczące posiadania (materialne). Zidentyfikowano również wątki rzadziej reprezentowane, takie jak: marzenia o wydźwięku dobra ogólnoludzkiego (idealistyczne), dotyczące chęci poznania kogoś znanego, drobne marzenia "tu i teraz" oraz będące mieszanką wymienionych kategorii. Pojawią się one kolejno według częstości występowania w wypowiedziach uczniów.

1. Marzenia związane z pracą, karierą zawodową, artystyczną to najliczniej reprezentowana kategoria (co drugi uczeń podawał przykłady tego rodzaju marzeń - 28 na 62). Przykłady te różnią się m.in. stopniem realizmu:

Moim największym marzeniem jest to, że po skończeniu szkoły chciałbym poszukać jakiejś pracy. Jakiś dobry zawód znaleźć, np. takiego pomocnika, co pomaga w kuchni albo jak być kucharzem. Zawód kucharza by mi odpowiadat. Tata twierdzi, że zawód policjanta jest dla mnie za trudny (D1, G, C).

Najbardziej chciatabym być kelnerką (D47, SP, D).

W przyszłości chciatbym być stolarzem. Meble bym robit, np. huśtawki (D66, SP, C). Żeby zostać policjantem (D10, G, C).

Chcę być organistą (D20, G, C).

Największym moim marzeniem jest zrobienie prawa jazdy na samochód. Chciałbym być handlowcem $i$ handlować. Chciałbym mieć własna firmę i chciałbym sprzedawać. Chciatbym mieć wtasna ubojnię czy rzeźnię i gdzieś to mięso sprzedawać (D67, $\mathrm{G}, \mathrm{C})$. 
Niektóre wypowiedzi dotyczące przyszłej pracy wyrażają chęć pomagania, opiekowania się innymi, np.:

Chce zostać księdzem. Czuje takie powotanie, bo wtedy można pomagać ludziom (D29, G, C).

Bardzo chciałabym zostać opiekunka małych dzieci. Chciałabym opiekować się małymi pieskami i kotkami. Np. mogłabym pracować w schronisku dla zwierząt. Chciałabym, żeby moje życie dobrze się potoczyło (D61, G, D).

W innych wypowiedziach zawarty jest również motyw kariery artystycznej lub sportowej:

Moim marzeniem jest zajmowaniem się muzyka. Chciatbym pisać teksty i założyć swój zespót. Chciałbym występować na scenie, w telewizji (D62, G, C).

Moim największym marzeniem jest to, żeby zostać pitkarzem (D27, SP, C).

W pojedynczych wypowiedziach pojawiają się też marzenia związane ze sposobem spędzania wolnego czasu, zgodnie z własnymi zainteresowaniami, np.:

Chciałbym być wędkarzem (D17, G, C).

2. Kategoria „brak marzeń" - jeden na dziesięciu uczniów podaje, że nie ma marzeń (6 uczniów) albo nie wie (nie potrafi sprecyzować), jakie są jego/jej marzenia (3 uczniów), np.:

Jeszcze nie mam największego marzenia (D3, G, C).

Na razie to nie mam jakiegoś największego marzenia (D22, G, C).

Nie wiem (D50, SP, D).

Nie wiem. Dużo tego (D9, G, D).

W jednej wypowiedzi widoczne jest rozczarowanie i porzucenie niespełnionego z powodu niepełnosprawności marzenia:

Jeszcze nie wiem, nie zastanawiatem się nad tym. Moim niespetnionym marzeniem jest to żeby zostać stolarzem, ale przez wadę wzroku nie mogę (D7, G, C). 
Inna z odpowiedzi w tej kategorii dotyczyła "programowego" nieposiadania marzeń:

Ja ogólnie to nie lubię marzyć, bo jeśli nie marzysz, to nie jest Ci żal. Jeśli później przyjdzie na to czas, to w końcu się to spetni (D51, SP, C).

Zwraca tu uwagę swoista pesymistyczna dojrzałość.

3. Marzenia związane z posiadaniem (materialne), które mają zarówno ograniczony, jak i szeroki charakter, np.:

Moim największym marzeniem jest mieć nowy plecak albo dostać loda (D32, G, D).

Moim marzeniem jest dostać gry komputerowe o samochodach (D33, G, C).

Chciałbym być bogaty (D19, G, C).

Wydaje się, że marzeń o charakterze materialnym jest stosunkowo mało wśród badanych uczniów (8 wypowiedzi), biorąc pod uwagę dość powszechny dziś konsumpcjonizm i komercjalizację dzieciństwa.

4. Marzenia o charakterze „ucieczkowym” (3 wypowiedzi), które najczęściej dotyczą jakiejś trudnej sytuacji rodzinnej, rówieśniczej lub osobistej.

Moje marzenie? Wyprowadzić się gdzieś najdalej od niektórych osób. Od niektórych koleżanek $i$ kolegów tutaj ze szkoły, no i od mojej rodziny, np. od rodziców i brata. To moje i mojej cioci marzenie, żeby wyprowadzić się gdzieś do (X) i odpoczać od nich (D25, G, D).

Uwolnić się od mamy oraz rodziny, której nie lubię, aby mój brat Mateusz nie przychodzit do mnie tak często. Inne to żeby wyjść stąd, mieć swoją rodzinę, dom, prace i spokój jak normalny człowiek, a nie czuję się, jak ktoś z domu dziecka albo z ośrodka dla osób psychicznie chorych, albo szkoły specjalnej, gdzie mówia, że on jest nienormalny (D31, G, C).

Żeby jak będę dorosta to gdzieś daleko wyjechać. Choćby na jeden dzień. Do Nowego Jorku albo do Londynu. Tam jest tadnie, dużo się w nich dzieje (D36, SP, D).

5. Marzenia, których treścią jest podróżowanie, wyjazdy, zmiana otoczenia, gdzie niekiedy pojawia się też motyw "ucieczkowy" (3 wypowiedzi): 
Chciałbym wyjechać na miesiąc nad nasze polskie morze. Nie wiem konkretnie gdzie. Troche bym poleniuchowat (D42, SP, C).

Lubię wyjeżdżać na wakacje, coś zwiedzić (D35, G, C).

Zdaniem niektórych respondentów wyjazd to możliwość intensywniejszego doświadczania, przeżycia przygody, ryzyka, wreszcie okazja do autoprezentacji:

Największym marzeniem jest wyjechać do Hiszpanii albo do Anglii i zwiedzić te kraje. Zrobić zdjęcia na pamiątkę i na Facebooka wrzucić. Jakąś przygodę przeżyć, bo lubię ryzyko. Marzy mi się też skok na bungee (D12, G, C).

6. Marzenia "tu i teraz” (3 osoby), które mają bardzo konkretny, ograniczony charakter i koncentrujące się bardziej na codzienności niż przyszłej (odległej) perspektywie:

Moim największym marzeniem jest zdać do trzeciej klasy gimnazjum, to jest moje największe marzenie (D30, G, D).

Chciałbym sam ściany pomalować na kolor zielony i umieć skorzystać z Facebooka, żeby móc komunikować się z ludźmi (D54, SP, C).

Kwestia marzeń związanych z wykorzystywaniem nowych mediów pojawia się również w innych kontekstach, np.:

Moim największym marzeniem jest zagrać w grę, taka gdzie można łapać łobuzów. To jest gra, gdzie sie jedzie radiowozem, gonisz tobuza $i$ kiedy go dogonisz, to wysiadasz i go zabijasz albo zakuwasz w kajdanki. Bardzo lubię policje (D37, SP, C).

7. Marzenia dotyczące spotkania z osobami znanymi z mediów (2 wypowiedzi):

Mam marzenie. Chciatabym wyjechać i spotkać się z Beckhamem (D11, G, D).

Moim największym marzeniem jest poznać Tomasza Adamka (D13, G, C).

8. Marzenia odnoszące się do dobra ogólnoludzkiego, idealistyczne (2 wypowiedzi): 
Jeżeli mam marzenie, to chyba żeby ten świat byt lepszy (D6, G, C).

W marzeniach mogą się również łączyć wątki na pozór sprzeczne: ogólnoludzkie i bardzo osobiste, związane z potrzebą wsparcia innych osób:

Żeby wszyscy żyli, mogli mi pomagać i być ze soba (D39, SP, C).

9. Marzenia (3 wypowiedzi) będące mieszanką wcześniejszych kategorii, w których pewne wątki nakładały się na siebie, np.:

Moim marzeniem jest zrobienie prawa jazdy. Chciałbym także kupić sobie kiedyś samochód. Chciałbym też kupić sobie mieszkanie na (X), najlepiej trzypokojowe. Chciałbym zostać maszynista metra warszawskiego. Chciałbym zostać redaktorem radia (X). Robitbym wywiady z mikrofonem i pomagat (D53, SP, C).

\section{Zakończenie}

Marzenia uczniów z niepełnosprawnością intelektualną mają zróżnicowany charakter. W dużej części cechują się znacznym stopniem realizmu - życiowego rozsądku. Wyniki pokazują, że największe znaczenie dla badanych uczniów ma wizja przyszłości związana z pracą zawodową jako źródłem satysfakcji życiowej. Znaczenie rehabilitacyjnej wartości pracy dla osób z niepełnosprawnością intelektualną jest szeroko opisywane w pedagogice specjalnej, a takie wyniki potwierdzają również wartość działań w obszarze rehabilitacji zawodowej. Ograniczony charakter badań, np. w zakresie eksplorowanych zmiennych, nie pozwala jednak na wyciąganie daleko idących wniosków. By stało się to możliwe, niezbędne jest pogłębienie i poszerzenie spektrum podejmowanych problemów, zmiennych i umocowanie teoretyczne. Wartością prezentowanej analizy jest zaś to, że w kolejnych badaniach będzie można zweryfikować trafność wyodrębnionych kategorii marzeń uczniów z niepełnosprawnością intelektualną i uczynić je dla nich punktem odniesienia. 